\title{
A Review On Pharmalogical Study Of Datura Stramonium L. Jahnavi Pandya ${ }^{1}$, Sanjukta Rajhans ${ }^{2}$,Dr. Archana Mankad ${ }^{3}$ \\ Department Of Botany Bioinformatics and Climate Change Impact Management, School of Science, Gujarat University Ahmedabad 383009 Gujarat \\ jahnavipandya63@gmail.com ${ }^{1}$,sanjuktarajhans@gmail.comaumankad@gujaratuniversity.ac.in
}

\section{INTRODUCTION}

Plants have always played a major role in the treatment of human traumas and diseases worldwide. The demand for medicinal plant is increasing in both developed and developing countries due to growing recognition of natural product. Herbal medicine is an important part of both traditional and modern system of medicines [Kirtikar JD et al., 1994]. Datura stramonium L. (D. stramonium) is a widespread annual plant of the Solanaceae family. It is one of the widely well-known folklore medicinal herb. It is a wild growing flowering plant and was investigated as a local source for tropane alkaloids which contain a methylated nitrogen atom $\left(\mathrm{N}-\mathrm{CH}_{3}\right)$ and include the anti-cholinergic drugs atropine, and scopolamine. From ancient civilization it was traditionally used for religious visionary purposes throughout the world and used by witchcraft in medieval Europe. The god lord Shiva was known to smoke Cannabis and Datura. People still provide the small thorn apple during festivals and special days as offerings in Shiva icons at temple.

\section{SCIENTIFIC CLASSIFICATION OF DATURA STRAMONIUM L.}

Kingdom

Subkingdom

Superdivision

Division

Class

Subclass

Order

Family

Genus

Species

\section{Plantae}

Tracheobionta

Spermatophyta

Magnoliophyta

Magnoliopsida

Asteridae

Solanales

Solanaceae

Datura L.

D. stramonium L. (URL 3).

\section{BOTANICAL DESCRIPTION OF DATURA} STRAMONIUM L.

A glabrous (sometime farinose) annual herb, 50- $200 \mathrm{~cm}$, in height (Joshi, 2000). This plant is a bushy, smooth, fetid, annual plant, and in rich soil. The Thorn apple is a large and coarse herb, though an annual, branching somewhat freely, giving a bushy look to the plant. Its spreading branches covering an area almost as broad. On rich soil it may attain a height of even 6 feet. The plant is smooth, except for a slight downiness on the younger parts, which are covered with short, curved hairs, which fall off as growth proceeds. It exhales a rank, very heavy and somewhat nauseating narcotic odour. This foetid odour arises from the leaves, especially when they are bruised, but the flowers are sweetscented, though producing stupor if their exhalations are breathed for any length of time. (Keshari, 2005).

\section{ROOT}

The root is rather large of a whitish color, giving off many fibers, very long - thick. Root system consists of taproot that is shallow for the size of the plant; it branches frequently. (Keshari, 2005).

\section{STEM}

The stem is green or purple and largely hairless, although young stems often have conspicuous hairs, cylindrical, fistular. Stem is stout, erect and leafy, smooth, a pale yellowish green in color, branching repeatedly in a forked manner, and producing in the forks of the branches a leaf and a single, erect flower. (Keshari, 2005).

\section{LEAVES}

The alternate leaves are up to $8 \mathrm{~cm}$ long and $6 \mathrm{~cm}$ across (excluding the petioles). They are ovate or ovate-cordate in outline, but pinnately lobed. These lobes are somewhat shallow and pointed at their tips; there are usually 2-3 of these lobes on each side of the leaf blade. The margin of each leaf may have a few secondary lobes or coarse dentate teeth; otherwise it is smooth or slightly undulate. The leaves may be slightly pubescent when young, but become hairless with age; the upper surface of each leaf is often dark green and dull. The foliage of Jimsonweed exudes a bitter rank odor. Leaves are cauline and ramal, exstipulate; alternate to opposite, petiolate, simple, dissected, acute, glabrous, unicosted, reticular venation. The leaves are large and angular, uneven at the base, with a wavy and coarselytoothed margin, and have the strong, branching veins very plainly developed. The upper surface is dark and grayishgreen, generally smooth, the under surface paler, and when dry, minutely wrinkled (Keshari, 2005).

INFLORESCENCE

Solitary, erect axillary (Keshari, 2005). FLOWERS

Ebracteate, ebracteolate, pedicellate, actinomorphic, bisexual, complete, regular, pentamerous, except fourth whorl, hypogynous. The plant flowers nearly all the summer. The flowers are large and handsome, about 3 inches in length, growing singly on short stems springing from the axils of the leaves or at the forking of the branches. The flowers are succeeded by large, egg shaped seed capsules of a green color, about the size of a large walnut and covered with numerous sharp spines, hence the name of the plant. When ripe, this seed-vessel opens at the top, throwing back four valve-like forms, leaving a long, central structure upon which are numerous rough, dark-brown seeds. The appearance of the plant when in flower and fruit is so peculiar that it cannot be mistaken for any other native herb. (Keshari, 2005).

\section{CALYX}

Sepals 5, gamosepalous, tubular, five toothed, sepaloid, hairy, persistent, valvate aestivation, inferior. The calyx is long, tubular and somewhat swollen below, and very sharply five-angled, surmounted by five sharp teeth. (Keshari, 2005) . 
International Journal of Research in Advent Technology, Vol.7, No.3, March 2019

E-ISSN: 2321-9637

Available online at www.ijrat.org

\section{COROLLA}

Petals 5, gamopetalous, petals fused at the base, infundibuliform, surface hairy, white, twisted aestivation, inferior. The corolla, folded and only half-opened, is funnelshaped, of a pure white, with six prominent ribs, which are extended into the same number of sharp pointed segments. The flowers open in the evening for the attraction of nightflying moths, and emit a powerful fragrance. The funnel form corolla of each flower is up to 5" long and 2" across when fully open; its outer rim has 5 shallow lobes. Each of these lobes forms an acute point in the middle. The corolla is white or pale violet throughout, except at the throat of the flower, where thick veins of dark violet occur (Keshari; 2005).

\section{ANDROCIUM}

Stamens 5, polyandrous, alternipetalous, epipetalous, filament long and smooth, anthers dithecous, basifixed, introse, inferior (Keshari, 2005).

\section{GYNOCIUM}

Carpels two (bicarpellary), syncarpous, ovary posterior obliquely placed to the right and anterior to the left, superior, bilocular with many ovules on swollen placentae, axile placentation, style long, stigma small, bilobed and capitate (Keshari, 2005).

\section{FRUITS}

Each flower is replaced by a hard fruit that is dry and spiny; it is about $1 \frac{1 / 2}{2}$ long, $1 "$ across, and spheroid-ovoid in shape. Underneath each fruit is a truncated remnant of the calyx that curves sharply downward. These fruits are initially green, but become brown with maturity; they divide into 4 segments to release the seeds. (Keshari, 2005).

\section{SEEDS}

The large seeds are dull, irregular, and dark-colored; their surface may be pitted or slightly reticulated. Jimsonweed spreads by reseeding itself. (Keshari, 2005).

\section{DISTRIBUTION / HABITAT OF DATURA STRAMONIUM L.}

D. stramonium is naturalized to all four deserts of the American Southwest. Species of Datura can be found throughout the world, except in the colder or Artic regions. The plant lives in sandy flats, plains, arroyos up to 2,500 feet above sea level and amidst disturbed soils. Jimson weed is commonly seen among roadsides in the Southwest it is mainly found in The Himalaya from Kashmir to Sikkim up to $2700 \mathrm{~m}$, hilly district of central and south India. (Khare, 2007).

Being of tropical origin, D. stramonium is a cosmopolitan weed of the warmer regions of North, Central and South America, Europe, Asia, and Africa. It grows nearly throughout the United States except for the Northwest and northern Great Plains, and as such is found throughout Pennsylvania. It is essentially a temperate plant but is found growing in the vicinity of cultivation, on rank soil, where refuse is deposited, in all parts of world. (Joshi, 2000)

Datura is distributed throughout the world, particularly the warmer regions. D. stramonium is indigenous to India. Out of 15 species reported from different parts of the world, only 10 are known to occur in
India. They are found commonly in wastelands, gardens and roadsides. They are distributed in rich localities under semiarid and arid regions of Punjab, Haryana, Rajasthan, and Gujarat; the Central Plateau of Andhra Pradesh and Maharashtra and the southern peninsular region of Tamil Nadu. D. stramonium is Indigenous to Mexico and is distributed in Latin American countries. A wealth of genetic stock on genotypes and varieties are maintained in several research institutes in Germany, Bulgaria, USSR and Poland. Geographic distribution of D. stramonium is widely present across the United States. It has been reported in every state except Alaska and Wyoming. (URL 1,2).

Although most commonly found in agricultural areas, especially where grazing is present, the plant can thrive in a wide variety of climatic condition. In nonagricultural areas it can be located on the side of roads, where the soil has been disturbed. In California, the presence of Jimson weed has been expertly confirmed in every county along the coast except Del Norte and Mendocino, and its presence completely encircles the Bay Area. In Southern California the plant is present in every county along the coast and also inland in San Bernadino and Kern Counties. Jimson weed can be observed mostly in disturbed areas, like roadsides, agricultural fields and stream banks. While the plant can survive in numerous moisture regimes, it is most prevalent in a xeric regime (hot, dry summer, wet, cool winter). It requires an abundance of sunlight, and is rarely found in heavily wooded areas. It is not found in mountainous areas above the tree line. Although D. stramonium has an annual or short perennial life cycle, the seeds can remain viable for long periods of time, perhaps explaining its wide distribution throughout the United States. (URL 1, 2).

\section{CULTIVATION AND COLLECTION}

Thorn apple is easily cultivated, growing well in open, sunny situation. It flourishes in moderately good soil but grows best in calcareous rich soil, or in a good sandy loam, with leaf mould added. Seeds are sown in open in May, in drill 3 feet apart, barely covered. Sown thinly, as the plants attain a good size and grow freely from seed. Thin out the young plants to a distance of 12 to 15 inches between each plant in the drill. The soil should be kept free from weeds in the early stages. If the summer is hot and dry, give a mulching of rotted cow-manure. If grown for leaf crop, the capsule should be picked off as soon as formed, as in a wind the spines tear the leaves. In August the plant reaches to a height of 1 meter and bears flowers and fruits. In the end of August stems with leaves and flowering tops are collected and dried as soon as possible at $45^{\circ} \mathrm{C}$ to $50{ }^{\circ} \mathrm{C}$. The leaves should be gathered when the plant is in full bloom and carefully dried. They are generally harvested in late summer. In August, the crop is cut by the sickle on a fine day in the morning, after the sun has dried off the dew, and the leaves are stripped from the stem and dried carefully as quickly as possible. (Jarald E, et al., 2007 and Gupta DP et al., 2008 and Gary I et al., 2005). 


\section{PHARMACEUTICAL VALUE OF DATURA STRAMONIUM L. ETHANOMEDICINAL VALUE}

Plant derived drugs come into use in the modern medicine through the uses of plant material as indigenous cure in folklore or traditional systems of medicine. The leaves of D. stramonium L. are used for the relief of headache and vapours of leaf infusion is used to relive the pain of rheumatism and gout. The smoke from the burning leaf is inhaled for the relief of asthma and bronchitis. European remedy of D. stramonium for haemorrhoid is to steam the part over boiling water containing leaf. The fruit juice is applied to the scalp for the treatment of falling hair and dandruff. It is also applied to smooth painful wounds and sores. Seeds and leaves of D. stramonium were used to sedate hysterical and psychotic patients, also to treat insomnia (pandey $\mathrm{M}$ et al., 2011). D. stramonium was used as hallucinogenic drug. It is also used to relax the smooth muscles of the bronchial tube and asthmatic bronchial spasm. It was reported that D. stramonium was used internally to treat madness, epilepsy and depression. Externally it forms the basis of ointment for burns and rheumatism (Paolo et al., 2001). It is also used in the treatment of Parkinsonism and hemorrhoids. Its leaves, applied after roasting, are useful in relieving pain. The bitter narcotic plant relieves pain and encourages the healing process. The seeds of the plant are medicinally the most active. Externally, the plant is used as a poultice in treating fistulas, abscesses wounds and severe neuralgia. Scopolamine is also found in the plant, which makes it a potent cholinergic-blocki hallucinogen that has been used to calm schizoid patients. Its leaves, containing hyoscyamine and atropine, can be used as an immensely powerful mindaltering drug. The seeds of Datura are analgesic, anthelmintic and anti-inflammatory and as such, they are used in the treatment of stomach and intestinal pain that results from worm infestation, toothache, and fever from inflammation. The juice of its fruit is applied to the scalp, to treat dandruff and falling hair. The growing plant works as an insect repellant, which protects neighboring plants from insects (Das S et al., 2012). D. stramonium is mostly used as anthelmintic and ant parasitic in Marche, Abruzzo and Latium. Records of continued use of the plant in these sectors was collected from farmers and shepherds.

\section{PHYTOCHEMICALS}

The major tropane alkaloids hyoscyamine and scopolamine and several minor tropane alkaloids have been identified in Datura species. Typical examples of minor alkaloids in D. stramonium are tigloidin, aposcopolamine, apoatropin, hyoscyamine $\mathrm{N}$-oxide and scopolamine $\mathrm{N}$-oxide17-20. 6 ditigloyloxytropane and 7-hydroxyhyoscyamine are reported for the first time in this species (Das S et al., 2012). Distribution of hyoscyamine and scopolamine in D. stromonium was studied. The production of hycyamine and scopolamine in D. stromonium has been investigated in the different plant parts, at different stages of their life cycle. The maximum contents were found in the stems and leaves of young plants, hyocyamine being always the predominate component. These compounds were included in many pharmacopieas because of their anticholinergic activities (shagal MH et al., 2012). D. stramonium contain variety of alkaloids including atropine, hyoscamine and scopolamine (ivancheva S et al., 2006). Sixty-four tropane alkaloids have been detected from D. stramonium. Two new tropane alkaloids, 3-phenylacetoxy-6, 7-epoxynortropane and 7hydroxyapoatropine were tentatively identified. The alkaloids scopoline, 3-(hydroxyacetoxy) tropane, 3hydroxy-6-(2-methylbutyryloxy) tropane, 3-tigloyloxy-6hydroxytropane, 3, 7-dihydroxy-6-tigloyloxytropane, 3tigloyloxy- 6-propionyloxytropane, 3 phenylacetoxy-6,7epoxytropane, 3-phenylacetoxy-6-hydroxytropane, aponor scopolamine, 3,6 -ditigloyloxytropane and 7hydroxyhyoscyamine are reported for the first time for this species. Other alkaloids found in D. stramonium include (strahil B et al.,2006): Hygrine, 3á, 6-Ditigloyloxy- 7hydroxytropane, 6-Hydroxyhyoscyamine, Pseudotropine, 3á-Tigloyloxytropane, Hydroxy-6-tigloyloxytropane, Phenylacetoxytropane, 3-Tigloyloxy-6-(2methylbutyryloxy) tropane, Hyoscyamine, 3-Tigloyloxy-6isovaleroyloxy-hydroxytropane, Scopolamine, Tropinone, Scopine, 6-Hydroxyacetoxytropane, 3,6-Diacetoxytropane, 3-Tigloxyloxy-6-acetoxytropane, 3-Tigloyloxy-2methylbutyryloxytropane, 3á, 6-Ditiglotoxytropane, 3Acetoxy-6-isobutyryloxytropan, 3-(2-Phenylpropionyloxy) tropane, Littorine, 6-Hydroxyapoatropine, 3, 6Ditigloyloxy- 7-hydroxytropane, 3-Tropoyloxy-6acetoxytropane, 3,6-Dihydroxytropane, 3Tigloyloxytropane, 3-Tigloyloxy-6- propionyloxy-7hydroxytropane, 3á-Apotropoyloxytropane, Aposcopolamine, 3, 6-Ditigloyloxytropane, 3-(3'Acetoxytropoyloxy) tropane, 3á-Tigloyloxy-6hydroxytropane, Tropine, 3-Acetoxytropane, 3-Hydroxy-6acetoxytropane, 3-Hydroxy-6-methylbutyryloxytropane, 3Tigloloxy-6- isobutyryloxytropane, Aponorscopolamine, 7Hydroxyhyoscyamine, Meteloidine, 3, 6Ditigloyloxytropane. The phytochemical analysis of the plant revealed that D. stramonium contained saponins, tannins and alkaloids and glycosides. The secondary metabolites identified in the plant materials in the study of Banso A, Adeyemo S showed antimicrobial activity. (Banso A et al., 2006).

\section{PHARMACOLOGICAL ACTIVITY}

\section{Antiasthmatic Activity}

D. stramonium in asthma treatment and possible effects on prenatal development was studied. Exposure of the foetus to D. stramonium when a mother use it for asthma, will cause a continuous release of acetylcholine, resulting in the desensitization of nicotinic receptors, this could ultimately result in permanent damage to the foetus. Therefore we conclude that this African herbal remedy should be used with caution during pregnancy. (Pretorius E et al., 2006).

\section{Anticholinergic Activity}

The alkaloids found in D. stramonium, are organic esters used clinically as anticholinergic agents. Jimson weed has been reported as a drug of abuse and has been involved in the accidental poisoning of humans and animals. Symptoms of acute jimson weed poisoning included dryness of the mouth and extreme thirst, dryness of the skin, pupil dilation and impaired vision, urinary retention, rapid heartbeat, confusion, restlessness, hallucinations, and loss of 
International Journal of Research in Advent Technology, Vol.7, No.3, March 2019

E-ISSN: 2321-9637

Available online at www.ijrat.org

consciousness. The anticholinergic syndrome results from the inhibition of central and peripheral muscarinic neurotransmission. (Taha SA et al., 1984 and Diker D et al., 2007)

\section{Acaricidal, Repellent And Oviposition Deterrent Properties}

The ethanol extracts obtained from both leaf and seed in D. stromonium (Solanaceae) were investigated for acaricidal, repellent and oviposition deterrent properties against adult two-spotted spider mites (T. urticae Koch) (Acari: Tetranychidae) under laboratory conditions. Leaf and seed extracts, which were applied in 167.25 and $145.75 \mathrm{~g} / \mathrm{L}$ concentrations, respectively (using a Petri leaf disc-spray tower method), caused $98 \%$ and $25 \%$ mortality among spider mite adults after $48 \mathrm{~h}$. These results suggest that D. stramonium extracts could be used to manage the twospotted spider mite. (kurnal NA et al.,2009) .

\section{Antimicrobial Activity}

The methanol extracts of D. stromonium L. and Datura inoxia L. showed activity against Gram positive bacteria in a dose dependent manner. Little or no antimicrobial activity was found against Escherichia coli and Psuedomonas aeruginosa [gupta $S$ et al., 2010]. The anti-microbial activity of combined crude ethanolic extract of D. stromonium, Terminalia arjuna and Withania somnifera in cup plate diffusion method for antibacterial and antifungal activity. The extracts were subjected to screening to detect potential antimicrobial activity against Staphylococcus aureus, Bacillus subtilus, Escherichia coli, Klebsiella pneumoniae, Micrococcus luteus and Candida albicans with compare Ciprofloxacin standard drug (sharma MC et al., 2010).

\section{Anticancer Activity}

An integrated approach is needed to manage cancer using the growing body of knowledge gained through scientific developments. Thousands of herbal and traditional compounds are being screened worldwide to validate their use as anticancerous drugs. D. stromonium in therapeutic dose of $0.05-0.10 \mathrm{~g}$ was used to cure cancer. Likely unsafeproduce vomiting, hypertension, loss of consciousness may lead to coma but may interact with anticholinergic drugs (balachandran et al., 2005).

\section{Antiinflamatory Activity}

Coriandrum sativum (C. sativum), D. stromonium and Azadirachta indica (A. indica) are traditionally used intreatment of inflammation. Ethanolic extracts of fruits of C.sativum, leaves of D. stromonium. Ethanolic extracts of fruits of C. sativum, leaves of D. stromonium and A. indica were subjected to preliminary screening for antiinflammatory activity in albino rats. All ethanolic extracts exhibited significant anti-inflammatory activity comparable to the standard drug diclofenac sodium against carrageenan induced rat paw edema method. Among these plant A. indica showed maximum anti-inflammatory activity per hour (Gupta S et al., 2010).

\section{Larvicidal And Mosquito Repellent Activities}

Ethanolic extracts of leaves of D. stromonium were evaluated for larvicidal and mosquito repellent activities against Aedes aegypti, Anopheles stephensi and Culexquinque fasciatus. The LD50 values for larvicidal activity were found to be $86.25,16.07$ and $6.25 \mathrm{mg} / \mathrm{L}$ against Aedes aegypti, Anopheles stephensi and Culex quinque fasciatus respectively. The ethanolic leaves extract of D. stromonium provided complete protection time (mosquito repellency) of 2.7, 71.7 and $117.7 \mathrm{~min}$ against Aedes aegypti, Anopheles stephensi and Culex quinque fasciatus at higher concentration (1\%)( Swathi S et al.,2012) Antifungal Activity

Antifungal activity of a concoction brewed from D.stromonium, Calotropis gigantea, A. indica (neem) and cow manure (T1) followed by methanol-water (70/30 v/v) extracts of D. stromonium, Calotropis gigantea and A. indica T2 against Fusarium mangiferae. The study proved that the concoction-brewed compost $\mathrm{T} 1$ is effective, inexpensive,easy to prepare and constitutes a sustainable and ecofriendly approach to control floral malformation in mango when it is sprayed at bud break stage and again at fruit set stage (Usha K et al., 2009).

\section{CONCLUSION}

Present review gives a broad information about the bioactive constituents, ethno pharmacology along with the scientifically claimed medicinal uses of D. stramonium. Several alkaloids, carbohydrates, fat, proteins and tannins have been reported to be present in different parts D. stramonium. The plant shows various types of activities such as analgesic and antiasthamatic activity which may be due to the presence of the investigated active chemical constituents. The pharmacological studies so far have been performed in vitro and in vivo. Therefore, there is a need of investigation and quantification of phytoconstituents and pharmacological profile. Datura stramonium is an Indian medicinal plant widely used in phytomedicine to cure diseases such as asthmas, cough, convulsions and other various human ailments. The plant may be explored further as per its great variety of traditional uses and on the basis of its reported chemical profile. But a great caution is advised since excess dose cause severe intoxication and death. The toxic dose is very close to the medicinal dose so this plant should only be used under the guidance of a qualified practitioner.

\section{REFERENCES}

[1] Balachandran P, Rajgopal G. (2005): Cancer-an ayurvedic perspective. Pharm Res, 51(1): 19-30.

[2] Banso A, Adeyemo S. (2006): Phytochemical Screening and antimicrobial assessment of Abutilon mauritianum, Bacopa monnifera and Datura stramonium. Biokem, 18(1): 39-44.

[3] Das S, Kumar P, Basu SP. (2012): Review article on phytoconstituents and therapeutic potentials of Datura stramonium linn. J Drug Del Therap, 2(3): 4-7.

[4] Diker D, Markovitz D, Rothman M, Sendovski U. Coma (2007): as a presenting sign of Datura stramonium seed tea poisoning. Eur J Int Med, 18(4): 336-338.

[5] Gary I, Stafford A, Anna K, Jager B, Johannes VS. (2005): Activity of traditional South African sedative and potentially CNSacting plants in the GABA- benzodiazepine receptor assay. J Ethnopharm 100: 210-215. 
[6] Gupta DP. (2008): The herb, habitat, morphology and pharmacognosy of most important popular Indian medicinal plant. 1st ed. Madhya Pradesh: Printwell Offset Publisher; p. 185.

[7] Gupta S, Raghuvanshi M, Jain D. (2010): Comparative studies on anti-inflammatory activity of Coriandrum Sativum, Datura stramonium and Azadirachta Indica. Asian J Exp Biol Sci, 1(1): 151-154.

[8] Ivancheva S, Nikolova M, Tsvetkova R. (2006): Pharmacological activities and biologically active compounds of Bulgarian medicinal plants. In: Inperato F, editor. Phytochemisry: Advances in research. Kerala: Signpost, p. 87-103.

[9] Jarald E, Edwin S. (2007): Textbook of pharmacognosy and phytochemisctry. 1st ed. New Dehli: CBS Publisher and Distributors, p. 224.

[10] Joshi, S.G.(2010): Medicinal Plants. Oxford \& IBH Publishing Co. Pvt. Ltd., New Delhi. pp 370-371.

[11] Keshari AK,Ghimire KR,Mishra BS and Adhikari KK (2005): A textbook of Higher secondary Biology, (3rd Ed.), Vidhyarthi Pustak Bhandar,Bhotahity, Kathmandu, pp 403- 404.

[12] Khare CP (2007): Indian Meditional Plants, Rajkamal Electric Press, Delhi, India, pp 203.

[13] Kritikar KR and Basu BD (1999): Indian Meditional Plants (2nd Ed.), International Book Distributors, Dehradun, India, Volume III, pp 1783-1787.

[14] Kurnal NA, Yalcin SCC.(2009): Acaricidal, repellent and oviposition deterrent activities of Datura stramonium L. against adult Tetranychus urticae (Koch). J Pest Sci , 14: 54-57.

[15] Pandey M, Debnath M, Gupta M, Chikara SK.(2011): Phytomedicine: An ancient approach turning into future potential source of therapeutics. J Pharmacogn Phytother ,3(3): 27-37.

[16] Paolo MG.(2001): Traditional antihelmintic, antiparasitic and repellent uses of plants in Central Italy. J Ethnopharm, 68(1-3): 183-192.

[17] Pretorius E, Marx J. (2006): Datura stramonium in asthma treatment and possible effects on prenatal development. Environ Toxicol Pharm 21(3): 331-337.

[18] Shagal MH, Modibbo UU, Liman AB. (2012): Pharmacologicaljustification for the ethnomedical use of Datura stramonium stem-bark extract in treatment of diseases caused by somepathogenic bacteria. Int Res Pharm Pharmaco 2(1):16-19.

[19] Sharma MC, Sharma S.(2010): Phytochemical, preliminary pharmacognostical and antimicrobial evaluation of combined crude aqueous extract. Int J Microbiol Res, 1(3): 166-170.

[20] Strahil B, Rawia Z, Tsvetelina D. (2006): Alkaloid patterns in some varieties of Datura stramonium. Fitoterapia, 77(3): 179-182. 2005; 46: 81-82.

[21] Swathi S, Murugananthan G, Ghosh SK, Pradeep AS.(2012): Larvicidal and repellent activities of ethanolic extract of Datura stramonium leaves against mosquitoes. Int J Pharm Phytochem Res , 4(1): 25-27.

[22] Taha SA, Mahdi AW. (1984): Datura intoxication in Riyadh. Trans R Soc Trop Med Hgy , 78: 134135.

[23] Takhi D, Ouinten M.(2011): Study of antimicrobial activity of secondary metabolites extracted from spontaneous plants from the area of Laghouat, Algeria. Adv Environm Biol , 5(2): 469-476.

[24] Usha K, Singh B, Praseetha P, Deepa N, Agarwal DK, Agarwal R, et al.(2005): Antifungal activity of Datura stramonium, Calotropis gigantea and Azadirachta indica against Fusarium mangiferae and floral malformation in mango. Eur J Plant Pathol, 124(4): 637-657.

\section{WEB REFERENCE}

URL-1

http://content.herbalgram.org/abc/herbalgram/articleview.as $\mathrm{p} ? \mathrm{a}=2930$ (Acessed on March 25,

2019)

URL-2

http://ppjoy.tripod.com/PDFs/Bk\%20Medicinal\%20Plants.P DF (Accessed on March 25, 2019)

URL-3

http://www8.georgetown.edu/departments/physiology/cam/ urbanherbs/jimsonweed.html (Accessed on March 20, 2019) 